\title{
What Do Language Teachers Think about Interchange and American English File? Teacher's Evaluation of Two ESL Textbooks in Iran
}

\author{
Hassan Soleimani (Corresponding author) \\ Department of Foreign Languages, Payame Noor University, P.O. Box: 19395-4697 Tehran, Iran \\ Tel: 09128516093 E-mail: arshia.soleimani@gmail.com \\ Esmaeil Ghaderi \\ Department of Foreign Languages, Payame Noor University, P.O. Box: 19395-4697 Tehran, Iran \\ Tel: 09141591696 E-mail:ghaderi43@gmail.com
}

Received: 24-04-2013

doi:10.7575/aiac.ijalel.v.2n.5p.42
Accepted: 12-06-2013

Published: 01-09-2013

URL: http://dx.doi.org/10.7575/aiac.ijalel.v.2n.5p.42

\begin{abstract}
Materials evaluation is a critically significant feature of a coherent curriculum to achieve the objectives of pedagogy. To this end, two EFL textbooks commonly taught in language institutes in Iran, namely Interchange series and American English File, were selected for evaluation, seeking teachers' viewpoints on the effectiveness of the two textbooks. Thirty EFL teachers who had used these two textbooks in their teaching experience participated in the study. A modified version of Litz's (2005) teacher textbook evaluation form was used to collect data. Analysis of the collected data showed that the teachers were satisfied with the two materials. Moreover, it was found that the difference between the two textbooks was not significant in four features including practical considerations, layout and design, activities, and skills but this difference was significant in two features including language type as well as subject and content. The authors of the two textbooks, the administrators of language institutes, curriculum and material developers, and also students interested in learning EFL can benefit from the findings of this study.
\end{abstract}

Keywords: Interchange, American English File, curriculum, textbook evaluation

\section{Introduction}

There has been considerable controversy over the role of textbooks in a language course. Hutchinson and Torres (1994) claim that no teaching-learning situation, it seems, is complete without adopting its relevant textbook. They also believe that the textbook is an almost universal element of language teaching. Graves (2000) lists some advantages and disadvantages for using a textbook. Lamie (1999) believes that despite the development of new technologies that allow for higher quality teacher-generated materials, demand for textbooks is increasingly growing, and new series and textbooks are produced by the publishing industry each year. Razmjoo (2007) contends that working with textbooks gives students a sense of security, progress, and achievement. According to Riazi (2003), "textbooks play a very crucial role in the realm of language teaching and learning and are considered the next important factor in the second/foreign language classroom after the teacher"'(p. 52). Richards (2001) believes that without a textbook a language program may lose its central core and students may lack a systematically developed syllabus. While many of the aforementioned theorists emphasize the great benefits of using ESL/EFL textbooks, other researchers and practitioners are skeptical of this view and level some well-founded criticism against the use of textbooks. Researchers such as Florent and Walter (1989) and Carrell and Korwitz (1994) have criticized textbooks for their inherent social and cultural biases. Allwright (1981) sees textbooks as removing learners from negotiating the curriculum design process. Prabhu (1989) suggests that because teaching must be appropriate for the learners' current knowledge and level, textbooks will not be effective because they do not realize the state of this knowledge.

However, the fact that textbooks play pivotal roles in most educational contexts, especially in EFL environment, is not deniable. So it seems quite axiomatic that selecting a particular textbook for a particular group of learners can be a difficult job to handle. Also there is line of controversy whether teachers should have latitude to choose the materials or not. However, no one impugns the fact that any textbooks whether selected by the teacher himself or any educational systems should be evaluated. There are, in McDonough and Shaw's terms (2003), two situations in which textbooks should be evaluated. One is when the teacher has the freedom to adopt and develop his or her materials. Second is when the teacher is just prescribed and dictated what to teach and how to teach.

\subsection{Textbook Evaluation}

Today, language teaching largely is tied to commercial materials around the world and textbooks have the biggest share among them with an appealing and sophisticated design and supplementary resources (Richards, 1998). Selecting the right textbooks is a formidable task for teachers due to the wealth of the published materials for English language 
teaching (ELT) available in the market. Moreover, selection of a particular textbook for a given language program "signals an executive educational decision in which there is considerable professional, financial and even political investment" (Sheldon, 1988, p. 237).The idea of evaluating textbooks is seen by some experts to be intertwined with the selection of textbooks. The evaluation helps selection, which serves as an important decision making process.

Whether one believes that a textbook actually helps teaching and learning or that they are too inflexible and biased to be used directly as instructional material, it is undeniable that textbooks still maintain huge popularity and they will preserve this image. It is important to remember, however, that since 1970 there has been a trend to make learners the center of language instruction (learner centeredness). Likewise, the position of textbooks in educational system has changed. It is probably best to consider textbooks as resources in achieving the aims and objectives that have already been established taking into account the needs of the learner. In addition, textbooks should not necessarily establish the aims themselves or become the aims but they should always be at the service of the teachers and learners (Brown, 1995). As pointed out by Breen and Candlin (1987), Hutchinson and Waters (1987) and Tomlinson (2003) what is being taught should be relevant to learners. In other words, they should be in line with students' life and experiences or needs, and the objectives or goals of the program. As Williams (1983) states, "any textbook should be used judiciously, since it cannot cater equally to the requirements of every classroom setting" (p. 251).

Different definitions and interpretations for evaluation are proposed by different scholars. Evaluation of textbooks is typically considered to function as a kind of educational judgment. Hutchinson and Waters (1987) define evaluation as a matter of judging the fitness of something for a particular purpose. Richards, Platt, and Weber (1985) consider evaluation as "the systematic gathering of information for purposes of making decisions" (p. 98). Brown (1989) gives a rather comprehensive definition of evaluation. He defines it as "the systematic collection and analysis of all relevant information necessary to promote the improvement of a curriculum and assess its effectiveness within the context of the particular institutions involved" (p.223). Lynch (1996) defines evaluation as "the systematic attempt to gather information in order to make judgments or decisions" (p. 2).

Today, different attractive textbooks are published by different companies, thus making it even harder to choose one over the other. As Hutchinson and Torress (1994) claim, "the textbook not only survives, it thrives" (p. 316). This profusion makes the evaluation of textbooks essential. Ellis (1997) also highlights the need for textbook evaluation. Thus, evaluating different textbooks seems to be of great importance to the selection and exploitation of the most effective and contextually appropriate material. According to Sheldon (1988), we need to evaluate textbooks for two reasons. First, the evaluation will help the teacher or program developer in making decisions on selecting the appropriate textbook. Furthermore, evaluation of the merits and demerits of a textbook will familiarize the teacher with its content and consequently assist educators in identifying the particular strengths and weaknesses in textbooks already in use.

McDonough and Shaw (2003) have listed four reasons that highlight the importance of evaluation of textbooks. The first reason shows the importance of evaluation for teachers. They believe that writing their own materials can be very time-consuming and not cost-effective for the teachers. Therefore, evaluating the existing textbooks and adopting the most suitable one for the particular context can be an appropriate course of action for these teachers. The second reason stated by McDonough and Shaw (2003) to evaluate the textbooks is the fact that an inappropriate choice may waste time and funds and this may have a demotivating effect on both students and other teachers who will have to use the textbooks for many years. The third reason is the difficulty of the organizing authentic and stimulating materials. They emphasize the value of good textbook especially in situations where compiling an authentic and motivating textbook in an organized manner is a difficult job to handle. The fourth reason relates to the teachers whose course materials are supplied by the ministry of education or another authority. They have maintained that even those teachers might find evaluation a useful process which gives them insight into the organizational principles of the materials and helps them to keep up with the developments in the field.

Ellis (1998) has distinguished between macro and micro-evaluation in language teaching. He has proposed that macro evaluation is "an evaluation carried out for accountability and/or developmental purposes by collecting information relating to various administrative or curricular aspects of the program" (p. 218). As to micro evaluation, he maintains that it is "characterized by a narrow-focus on some specific aspects of the curriculum or the administration of the program" (p. 219).

Cunningsworth (1995) and Ellis (1997) have suggested three different types of materials evaluation. 'Predictive' or 'preuse' evaluation, probably the most common form, is planned to examine the future or potential performance of a material. The other types of material evaluation are the 'in-use' evaluation designed to test materials currently being used and the 'retrospective' or 'post-use' (reflective) evaluation which attempts to examine the material which has been used in any respective institution or educational system. McGrath (2002) believes that each stage has its own significance. While admitting some shortcomings, Tomlinson (2003) suggests that post-use evaluation is probably the most valuable one because it can assess both short and long term effects of the use of the textbook.

Similarly, McDonough and Shaw (2003) suggest an evaluation model with two stages: external evaluation and internal evaluation. External evaluation provides a brief "overview" of the materials from the outside. It relates to the organization of the material and promises made by the designer and author. Second, an internal evaluation requires an in-depth investigation into the materials. The types of used texts, the arrangements for self-study, the presentation of skills, the grading of the materials, and the suitability of tests and exercises are some of the factors considered in this stage. They believe that external evaluation should precede internal one. They point out that an overall assessment of 
the material examines the suitability of the materials taking into account the criteria, namely the usability, generalizability, adaptability, and flexibility factors.

\subsection{Textbook Evaluation Schemes}

There is a wide range of methods to properly evaluate a textbook. The review of textbook evaluation checklists within four decades (1970-2000) by Mukundan and Ahour (2010) has revealed that most of the checklists are qualitative. Moreover, most of these standardized evaluation checklists have similar criteria that can be exploited as helpful starting points for ELT practitioners throughout the world. Distinguished theorists in the field of ELT textbook development and evaluation such as Williams (1983), Sheldon (1988), Brown (1995), Cunningsworth (1995), and Harmer (1996) all agree that evaluation checklists should have some criteria pertaining to the physical characteristics of textbooks such as layout, organization, and logistical characteristics. They also include other important criteria that assess textbook's approaches, aims, methodology, and the degree to which a set of materials are matched with the needs of the learners, teacher's approach as well as the institution's curriculum. Language functions, grammar, skills as well as the relevance of linguistic items to the prevailing socio-cultural environment are also important factors to consider in evaluating the textbooks. Lastly, the criteria related to the representation of cultural and gender differences and the appropriateness of the linguistic items, subjects, content, and topics to the students' personalities, background, needs, and interests should be included in textbook evaluation.

Ansary and Babaii (2002) show that many scholars have suggested different ways to help teachers become more systematic and objective in their evaluation. Chastain (1971), Tucker (1975), Candlin and Breen (1979), Daoud and Celce-Murcia (1979), Williams (1983), Hutchinson and Waters (1987), Sheldon (1988), Skierso (1991), Ur (1996), Littlejohn, (1996), Litz (2005), and Razmjoo (2010) have proposed various checklists to evaluate EFL textbooks. They have often designed the checklists based on supposedly generalizable criteria. These sometimes detailed checklists use a variety of methods to assess the quality and suitability of a particular textbook for that context. Among these checklists, for instance, Cunningsworth (1984) emphasizes the importance of relating materials to course objectives and the learner's needs and processes. Sheldon's (1988) checklist is very broad and designed to assess all aspects of content including such various factors such as authenticity and flexibility as well as physical characteristics. Ansary and Babaii (2002), while admitting the popularity and practicality of the checklists, claim that the shaky theoretical foundation of such checklists and the subjectivity of judgments based on them have often been a source of disappointment.

In sum, in spite of having some drawbacks, checklist is an economical tool for textbook evaluation. It can provide a systematic way to ensure that all relevant items are considered (Cunninsworh, 1995; Mcgrath, 2002).It is also a flexible and suitable tool as evaluators can add or drop some items taking into account the context of administration.

\subsection{Research on textbooks/textbook evaluation}

A number of studies have been conducted on textbook evaluation all over the world. They emphasize the great significance of textbooks in language teaching and learning. Several of these studies centered on developing criteria for materials evaluation and selection. Studies done by Kearsey and Turner (1999), Xu (2004), and Altman, Ericksen, and Pena-Shaff (2006) are among these works. Several others have evaluated some particular materials. Gray (2000), Yakhontova (2001), and Morgan (2003) have evaluated different materials.

Litz (2005) evaluated English firsthand 2 used in all beginner EFL classes in one of the universities of Suwon, South Korea to find out its suitability for the intended language program. Litz (2005) believed that the book was appealing for many English language teachers and learners. Litz asserted that the textbook was communicative on the whole in that it constantly supported an activity approach towards teaching and learning. Tok (2010) examined the advantages and disadvantages of English language textbook "Spot On" used at primary schools in Turkey. He came to the conclusion that the textbook actually did not stand up reasonably well to a systematic in-depth analysis so that the negative attributes of it outweighed highly its positive characteristics.

Some studies have been conducted on textbook evaluation in Iran including Ansary and Babaii (2002), Yarmohammadi (2002), Khormaei (2005), Davatgarzadeh (2007), Iraji (2007), Zare Asl (2007), Razmjoo (2007), Dahmardeh (2009), Sarhady (2009), Gordani (2010), and Soozandehfar and Sahargard (2012). Some of these studies are discussed briefly.

Razmjoo (2007) conducted a comparative study in which he analyzed English high school textbooks and EFL institute textbooks, Interchange Series, to find out to what extent they are different in representing CLT principles. Using a combination of different textbook evaluation schemes based on CLT principles, he found that unlike the EFL private institute textbooks that represent the CLT principles to a great extent, English high school textbooks in Iran are not conducive to CLT implementation.

Dahmardeh (2009) claims new words in the textbooks under analysis are presented out of a plausible context as isolated sentences. Azizfar, Koosha, and Lotfi (2010) have stated that the materials designers have just focused on the mechanical drills. They contend textbooks are limited to substitution and repetition drills, and students are required to produce simple sentences with no opportunity to practice communicatively the language they are learning.

Gordani (2010) investigated different types of learning objectives inherent in Iranian guidance school English textbooks from the viewpoint of Bloom's taxonomy. He focused on the English textbooks taught in Iranian guidance schools at the present time. The results showed that all of the items were concentrated in the first three levels of Bloom's taxonomy which are referred to as the lower levels of cognitive skills. Soozandehfar and Sahargard (2012) conducted an in-depth 
evaluation of speech acts and language functions in Top Notch series. The results revealed that the conversations in these newly-arrived textbooks are not pragmatically efficacious and functional.

The present study investigates two global EFL textbooks. According to Bell and Gower (1998), a global textbook is "a textbook for a restricted number of teaching situations in many different countries rather than all teaching situations in all countries" (p. 117). Generally, global textbooks have both merits and demerits and it is up to teachers how they make use of them. Global textbooks are usually written for a wide audience. In particular, they are written both for inexperienced and experienced teachers. As for students, authors of global textbooks usually write for monolingual as well as multilingual classes in different ages. This broad scope brings some problems. For instance, students may be supposed to study topics which are uninteresting or culturally irrelevant to them (Bell \& Gower, 1998). The two textbooks under investigation in this study are Interchange and American English File. In other words, the study is going to elicit the evaluation of these two popular textbooks by EFL teachers in Iran. The main reason for choosing these two materials was their popularity in private language institutes in Iran. Moreover, as far as the researchers know, no study has investigated these two textbooks comparatively. Specifically, the study is going to answer these questions:

1. Are EFL teachers in Iran satisfied with two popular textbooks, namely Interchange and American English File?

2. Is there difference between Interchange and American English File in terms of practical considerations, layout and design, activities, skills, language type, subject and content from teachers' point of view?

\section{Method}

\subsection{Participants}

Thirty Iranian EFL teachers, having at least one year teaching experience of the books under study from different language institutes in Tehran, the capital of Iran, took part in this study. The participants were selected based on purposeful non-random sampling including both male and female teachers. Their age ranged from 23 to 40 . The questionnaires were administered to the participants directly and via e-mail. It was believed that the sampled teachers had a good command of the content, design, and objectives of the books.

\subsection{Materials}

The materials selected for evaluation were Interchange (by Richards, Hull, and Proctor, 2005) and American English File series (by Oxenden, Latham-Koenig, \& Seligson, 2008). Each book has composed of different units. Each unit consists of a topic and different sections to practice grammar points, functions, vocabularies, four skills, and pronunciation. The series, as stated in the blurb, follows a communicative paradigm underscoring the role of context and learners' engagement in the process of learning. The authors of the two books claim that the topics are motivating enough to raise students' interest and their books prepare learners for meaningful communication in English. They also point out that integration of the skills has been taken into account. The textbooks are supported by resources such as workbook, CDs, and a teacher's manual.

\subsection{Instrumentation}

After reviewing a number of checklists, the researchers decided to use a modified version of 10-point Likert-scale teacher textbook evaluation form developed by Litz (2005) ranging from 'highly agree' to 'highly disagree' . The reliability index of the questionnaire was calculated using Cronbach $(\alpha=.79)$. The questionnaire was composed of 36 items and had subcategories including practical consideration (1-5), layout and design (6-13), activities (14-20), skills (21-25), language type (26-31), subject and content (32-36). The validity of the instrument was established by a panel of EFL experts including instructors of EFL at different universities in Iran.

\subsection{Procedure}

Having reviewed some questionnaires and checklists, the researchers decided to use Litz's teacher textbook evaluation form. Some items were modified after discussing them in a panel of EFL experts. The questionnaires were sent to the participants directly and via e-mail. The respondents were asked to reflect on the experience they had in using the two textbooks in their classrooms and show their opinion about each item by choosing one of the options from 'highly agree' to 'highly disagree'. The questionnaires were sent to more than 50 teachers, but only 30 of the teachers responded and sent back the completed forms. Moreover, some of them evaluated only one of the textbooks which could not be included in our analysis. The collected data were analyzed using SPSS to find the answers to the posited research questions.

\section{Results}

After administering the questionnaires, the collected data were analyzed. Multivariate analysis of variance (MANOVA) was used to analyze the data. Table1 shows the descriptive statistics for the variables and features under question. 
Table 1. Descriptive Statistics

\begin{tabular}{llccc}
\hline & Textbook & Mean & $\begin{array}{c}\text { Std. } \\
\text { Deviation }\end{array}$ & $\mathrm{N}$ \\
\hline Practical & Interchange & 8.09 & 1.11 & 30 \\
considerations & American & 8.24 & 1.33 & 30 \\
& Total & 8.16 & 1.22 & 60 \\
Layout & Interchange & 7.61 & 1.18 & 30 \\
$\&$ & American & 8.08 & 1.92 & 30 \\
Design & Total & 7.84 & 1.59 & 60 \\
Activities & Interchange & 7.99 & 1.33 & 30 \\
& American & 8.16 & 1.83 & 30 \\
Skills & Total & 8.08 & 1.59 & 60 \\
& Interchange & 7.59 & 1.03 & 30 \\
& American & 7.95 & 1.60 & 30 \\
Language & Total & 7.77 & 1.35 & 60 \\
Type & Interchange & 6.87 & 1.20 & 30 \\
& American & 7.61 & 1.24 & 30 \\
Subject & Total & 7.24 & 1.27 & 60 \\
$\&$ & Interchange & 7.34 & 1.54 & 30 \\
Content & American & 8.27 & 1.05 & 30 \\
\hline & Total & 7.81 & 1.39 & 60 \\
\hline
\end{tabular}

Table 1 displays the mean and standard deviation of the six factors including practical considerations, layout and design, activities, skills, language type, and also subject and content for the two textbooks under study. The table shows that the mean of the textbooks in the six factors was high (more than the median=5.5) which implied the satisfaction of the teachers with the two textbooks. MANOVA was used to compare the significance of the differences in the six features in the textbooks. Table 2 shows the results of the analysis.

Table 2. Tests of between-subjects effects

\begin{tabular}{|c|c|c|c|c|c|c|}
\hline Source & $\begin{array}{l}\text { Dependent } \\
\text { Variable }\end{array}$ & $\begin{array}{c}\text { Type III } \\
\text { Sum of Squares }\end{array}$ & $\mathrm{df}$ & Mean Square & $\mathrm{F}$ & Sig. \\
\hline \multirow[t]{6}{*}{ group } & Practical considerations & .34 & 1 & .34 & .23 & .63 \\
\hline & Layout and design & 3.23 & 1 & 3.23 & 1.27 & .26 \\
\hline & Activities & .46 & 1 & .46 & .17 & .67 \\
\hline & Skills & 1.92 & 1 & 1.92 & 1.05 & .30 \\
\hline & Language type & 8.25 & 1 & 8.25 & 5.50 & .02 \\
\hline & Subject \& content & 12.87 & 1 & 12.87 & 7.35 & .009 \\
\hline \multirow[t]{6}{*}{ Error } & Practical considerations & 87.75 & 58 & 1.51 & & \\
\hline & Layout and design & 147.72 & 58 & 2.54 & & \\
\hline & Activities & 149.03 & 58 & 2.57 & & \\
\hline & Skills & 105.62 & 58 & 1.82 & & \\
\hline & Language type & 87 & 58 & 1.50 & & \\
\hline & Subject \& content & 101.48 & 58 & 1.75 & & \\
\hline \multirow[t]{6}{*}{ Total } & Practical considerations & 4092.21 & 60 & & & \\
\hline & Layout and design & 3847.52 & 60 & & & \\
\hline & Activities & 4067.33 & 60 & & & \\
\hline & Skills & 3735.36 & 60 & & & \\
\hline & Language type & 3244.80 & 60 & & & \\
\hline & Subject \& content & 3774.90 & 60 & & & \\
\hline
\end{tabular}


As Table 2 reveals, the difference between the means of the two textbooks was not significant in four features including practical considerations, layout and design, activities, and skills. In other words, the two textbooks had similar quality in the four aforementioned factors from the teachers' point of view. On the other hand, the difference between the textbooks in two features (language type as well as subject and content) was significant $(\mathrm{p}<0.05)$. Figure 1 shows the comparison of the components of the two textbooks graphically.

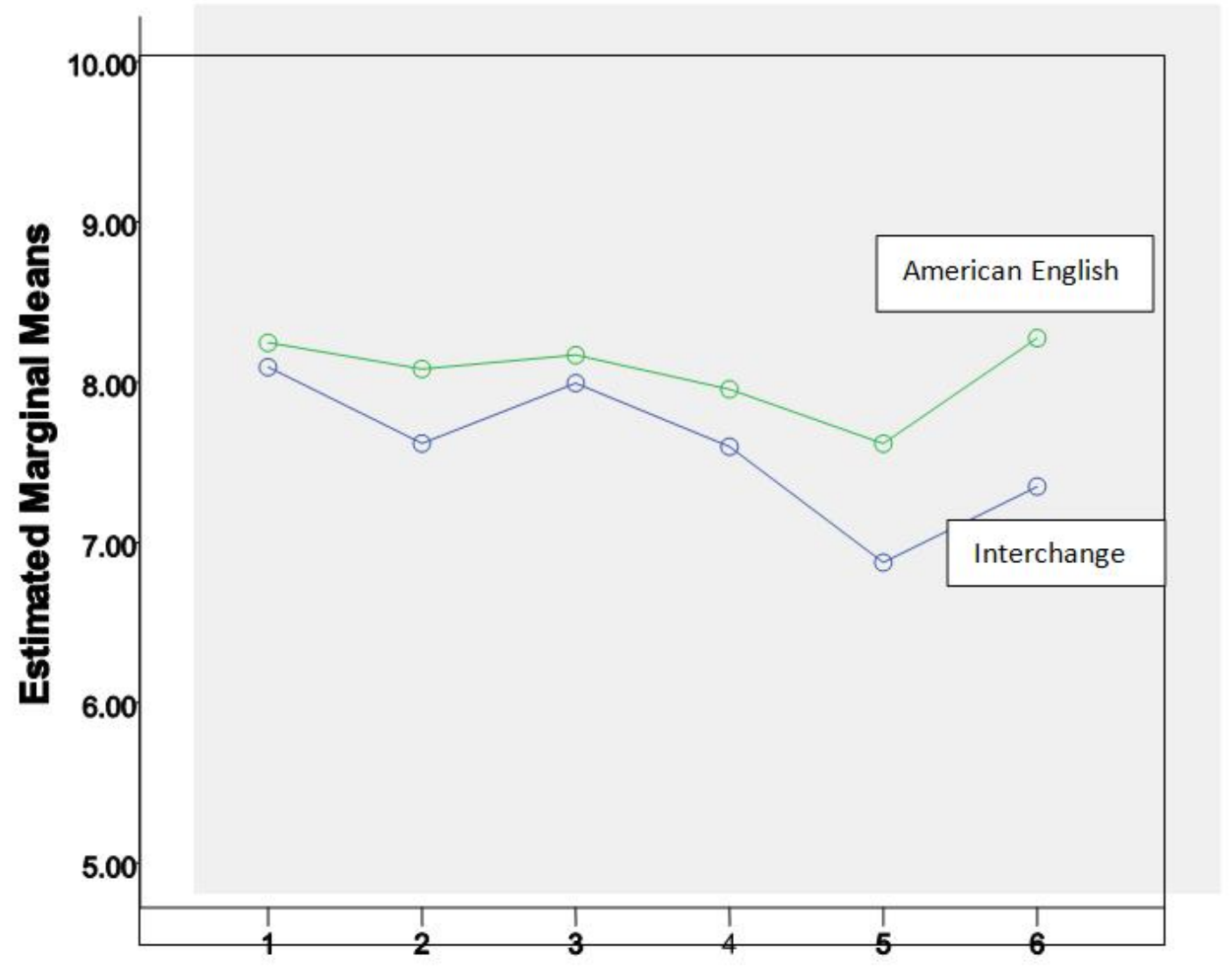

Figure 1. Comparison of the components of the books under study

1 practical considerations; 2 layout and design; 3 activities; 4 skills; 5 language type; 6 subject and content

\section{Discussion}

The importance and the role of the textbook in teaching and learning process are certainly recognized by both teachers and learners. In other words, there seems to be a general consensus among teachers and students in relation to the primary role of the textbooks. In spite of its great importance, materials evaluation has been a new trend in the process of language teaching. It does not have a long history. Tomlinson (2001) explains that the study of materials development had not received enough attention until the 1990s when books on this subject started to be published. This research was going to explore the quality of the two popular textbooks in the language institutes of Iran.

Analysis of the obtained data showed the high means for the features under study. The mean for the practical consideration, shown in Table 1, was 8.09 for Interchange and 8.24 for American English File. It shows that the teachers are satisfied with the price of the textbooks, their availability, recency of publication, providing supplementary supports and resources, and the authors' view on language methodology. Of course, the difference between the two textbooks is not significant in this criterion.

The second section of the questionnaire evaluated the layout and design of the two textbooks. The layout and design of a textbook refer to its organization and presentation of language items and activities. Questions regarding the organization of the textbook, functions, structures, and vocabularies taught in each unit as well as those considering the availability of adequate quizzes and also the clarity of objectives of materials for the teachers and students are included in this section. The high means of both the textbooks indicate the satisfaction of the teachers with the organization and layout of the books. The difference between the two books in this feature is not significant like the previous feature. Of course, most of the teachers were not satisfied with the glossary and vocabulary list of both textbooks.

The next section of the questionnaire explored the activities and tasks in the textbooks. Exercises and activities are nearly indispensible part of every textbook. They give students opportunities to practice and develop their language skills. For instance, activities that require students to negotiate for meaning in English (e.g., information gaps, jigsaw activities, role plays) can foster the oral skill and help students be prepared for the tasks in real-life contexts. Long 
(1990) cites five benefits of interactive group activities in comparison with teacher-fronted whole class instruction. Items in this section ask the respondents to evaluate the two books regarding the balance, flexibility, and variety of the activities and also their stimulating power to engage students in sufficient communicative and meaningful practice. The authors of the two books advertise that their book has the aforementioned characteristics. The teachers also seem happy with the activities of the two materials. High means of them for this section (7.99 for Interchange and 8.16 for American English File) have led us to this conclusion. Again the difference between the two materials is not significant.

The fourth section examined the skills in each textbook. Balance of four language skills, paying attention to sub skills (e.g. skimming and note keeping) and pronunciation, integration of skills, and the match between the learners' need and focus on the skills in the materials are the items included in this part. The difference between the two textbooks is not significant, but the high means of the textbooks (see Table 1) indicate the satisfaction of the teachers with the representation of the skills in these textbooks.

The next part was used to investigate the language type used in the two textbooks. The language type component encompasses six items that largely evaluate the view of the raters on the authenticity of the language of the textbook, the appropriateness of the language of the textbook for the target learners, the appropriateness of the progression of the grammatical points and vocabulary items, the presentation of grammatical points in conjunction with brief and easy examples, the match between the functions presented in the textbooks and those that the teachers and the learners will probably use, and finally the representation of the variety of the registers and accents in the language of the textbook. In this section, the difference between the two textbooks is significant $(p<0.05)$. Taken into account the higher mean of American English File (7.61) in comparison with Interchange (6.87), it can be concluded that the language type used in the former is better than the latter. Of course, most of the teachers were happy with the language type of Interchange, too.

The last part of the questionnaire examined the subject and content of the two textbooks. If students are not interested in topics of the textbook, learning will be futile. By learning new and challenging topics students should broaden their horizons and enrich their life experiences. Regarding the subject and content, being relevant to the student's needs, being realistic, being challenging and motivating, having variety and not being culturally biased are included in the items of this section. As shown in Table 2, the difference between the two books with respect to this section is significant and the higher mean of American English File (8.27) in comparison with Interchange (7.34) denotes the superiority of the former. Of course, the high mean of the latter can be the indicator of the satisfaction of the teachers with the subject and content of this book, too.

Overall, the two research questions posited for the study can be answered well now. Regarding the first research question, the answer is somehow "Yes". Considering the high means (more than the median) of the two textbooks in all of the six features being investigated, it can be inferred that the EFL teachers in our study are happy with these materials. Of course, this satisfaction is variable with respect to different features and textbooks. The second research question is also answered in this way that the difference between the two textbooks in two criteria including language type as well as subject and content was statistically significant. The respondents were more satisfied with American English File in two mentioned criteria. However, this difference was not significant in other four criteria including practical considerations, layout and design, activities, and skills. In other words, the level of satisfaction with the materials on the part of teachers was somehow similar in these four criteria.

\section{Conclusion}

Due to the popularity of two commonly practiced textbooks used in Iranian language institutes, the present study intended to examine the views of teachers teaching the textbooks. Using a formerly administered Likert scale questionnaire with different subcategories consistent with the research hypothesis, it was revealed that the teachers participated in the study were pleased with the two popular textbooks taught in the private language institutes. Moreover, the teachers' responses imply their more satisfaction with American English File than Interchange series in two components, namely language type as well as subject and content. The major limitation of the study can be the limited number of the participants. Of course, the researchers sent the questionnaires to more than 50 EFL teachers but only 30 of them were received and some of the respondents had only completed the evaluation form for one of the textbooks which could not be included in our analysis. Other researchers can evaluate other EFL textbooks using more participants in order to find the suitable EFL textbook for their educational context.

Findings of this study may offer insights for the authors of the textbooks as well as those involved in educational administrations, syllabus design, curriculum planning, and materials development and also the learners who are interested in learning EFL. Different sections of the textbooks can be modified by the textbook developers in order to improve their quality. Teachers may also get insights from the findings and employ different strategies to compensate for the weak points of the textbooks.

\section{References}

Allwright, R. L. (1981). What do we want teaching materials for? ELT Journal, 36(1), 5-13.

Altman, W.S., Ericksen, K., \& Pena-Shaff, J. (2006). An inclusive process for departmental textbook selection. Teaching of Psychology, 33(4), 228-231. Available online at: http://proquest.com. 
Ansary, H., \& Babaii, E. (2002). Universal characteristics of EFL/ESL textbooks: A step towards systematic textbook evaluation. The Internet TESL Journal, 8 (2). Retrieved September 3, 2012, from http://www.iteslj.org/

Azizfar, A., Koosha, M., \& Lotfi, A. R. (2010). An analytical evaluation of Iranian high school ELT textbooks from 1970 to the present. Procedia Social and Behavioral Sciences, 3, 36-44. http://dx.doi.org/10.1016/j.sbspro.2010.07.010

Bell, J., \& Gower, R. (1998). Writing course materials for the world: A great compromise. In B. Tomlinson (Ed.). Material development in language teaching (pp. 116-129). Cambridge: Cambridge University Press.

Breen, M.P., \& Candlin. C.N. (1987). Which materials? A consumer's and designer's guide. In L. E. Sheldon (Ed.), ELT textbooks and materials. Problems in evaluation and development (pp. 13-28). Oxford: Modern English Publications.

Brown, J.D. (1989). Language program evaluation: A synthesis of existing possibilities. In K. Johnson (Ed.), The second language curriculum. Cambridge: Cambridge University Press.

Brown, J. D. (1995). The elements of language curriculum. New York: Heinle \& Heinle Publishers.

Candlin, C.N., \& Breen, M.P. (1979). Evaluating, adapting and innovating language teaching materials. In C. Yorio, K. Perkins and J. Schacter (Eds.), On TESOL '79: The learner in focus (pp. 86-108). Washington, D.C.: Teachers of English to Speakers of Other Languages.

Carrell, D., \& Korwitz, J. (1994). Using concordancing techniques to study gender stereotyping in ELT textbooks. In: Sunderland J. (Ed.), Exploring gender: Questions and implications for English language education. Prentice Hall International.

Chastain, K. (1971). The development of modern language skills: Theory to practice (pp. 376-384). Philadelphia. The Center for Curriculum Development.

Cunningsworth, A. (1984). Evaluating and selecting EFL teaching materials. London: Heinemann.

Cunningsworth, A. (1995). Choosing your coursebook. Oxford: Heinmann.

Dahmardeh, M. (2009). Communicative textbooks: English language textbooks in Iranian secondary high schools. Linguistik, 40 (4), 45-61.

Daoud, A., \& Celce-Murcia, M. (1979). Selecting and evaluating a textbook. In M. Celce-Murcia and L. McIntosh (Eds.), Teaching English as a second or foreign language (pp. 302-307). Cambridge, MA: Newbury House.

Davatgarzadeh,G.(2007). The representation of social actors in Interchange third edition series: A critical discourse analysis with respect to the socio-semantic features. Unpublished master's thesis, Shiraz University, Iran.

Ellis, R. (1997). The empirical evaluation of language teaching materials. ELT Journal, 51(1), 36-42.

Ellis, R. (1998). The evaluation of communicative tasks. In B. Tomlinson. (Ed.), Materials development in language teaching (pp. 218 - 223). Cambridge University Press.

Florent, J., \& Walter, C. (1989). A better role for women in TEFL. ELT Journal, 43(3), 180-184.

Gordani, Y. (2010). An analysis of English textbooks used at Iranian guidance schools in terms of Bloom's taxonomy. The Journal of Asia TEFL, 7( 2), 249-278.

Graves, K. (2000). Designing language courses. Boston: Heinle \& Heinle Publishers.

Gray, J. (2000). The ELT coursebook as cultural artifact: How teachers censor and adapt. ELT Journal, 54(3), 274-283.

Harmer, J. (1996). The practice of English language teaching. Harlow: Longman.

Hutchison, T., \& Torres E. (1994). The textbook as agent of change. ELT Journal, 48(4), 315 -328.

Hutchinson, T., \& Waters, A. (1987). English for specific purposes: A learning-centered approach. Cambridge: Cambridge University Press.

Iraji, A. (2007). Pragmatic features of New Interchange: How communicative and task-based it is. Unpublished master's thesis, Shiraz University, Iran.

Jahangard, A. (2007). Evaluation of EFL materials taught at Iranian public high schools. ELT Journal, 9 (2), 130-150.

Kearsey, J., \& Turner, S. (1999). Evaluating textbooks: The role of genre analysis. Research in Science and Technological Education, 17(1), 35-43.

Khormaei, A. (2005). Lexis in English textbooks in Iran, analyses of exercises and proposals for consciousness-raising activities.Unpublished master's thesis, Shiraz University, Iran

Lamie, J. M. (1999). Making the textbook more communicative. The Internal TESL Journal, 5(1). Retrieved September 27, 2012, from www.iteslj.org.

Littlejohn, A. (1996). The analysis of language teaching materials: Inside the Trojan Horse. In B. Tomlinson, (Ed.), Materials development in language teaching (pp. 191-213). Cambridge: Cambridge University Press.

Litz, D. R. A. (2005). Textbook evaluation and ELT management: A South Korean case study (Doctoral Dissertation). Retrieved November 2, 2012, from http://www.asian-efl-journal.com/Litz_thesis.pdf 
Long, M. H. (1990). Task, Group, and Task-Group Interaction' in S. Anivan (Ed.), Language teaching methodology for the Nineties. SEAMEO Regional Language Centre.

Lynch, B. K. (1996). Language Program Evaluation: Theory and Practice. Cambridge: Cambridge University Press.

McDonough, J., \& Shaw, C. (2003). Materials and methods in ELT: A teacher's guide (2 $2^{\text {nd }}$ Ed.). Malden, MA: Blackwell Publishing Ltd.

McGrath, I. (2002). Materials evaluation and design for language teaching. Edinburg: Edinburg University Press.

Morgan, T. (2003). IELTS preparation materials. ELT Journal, 57(1), 66-76.

Mukundan, J., \& Ahour, T. (2010). A review of textbook evaluation checklists across four decades (1970-2008). In Tomlinson, B., Masuhara, H. (Eds.), Research for materials development in language learning: Evidence for best practice (pp. 336-352). London: Continuum.

Oxenden, C., Latham-Koenig, C., \& Seligson, P. (2008). American English file. USA: Oxford University Press.

Prabhu, N. S. (1989). Materials as support: Materials as constraint. Guidelines 11, 1: 66-74.

Razmjoo, S. A. (2007). High schools or private institutes textbooks? Which fulfill communicative language teaching principles in the Iranian context? Asian EFL Journal, 9(4). 126-140.

Razmjoo, S.A. (2010). Developing a textbook evaluation scheme for the expanding circle. Iranain Journal of Applied Language Studies,12(1), 121-136.

Riazi, A.M. (2003). What do textbook evaluation schemes tell us? A study of the textbook evaluation shemes of three decades. In W. Renandya (Ed.), Methodology \& materials design in language teaching. pp. 52-68. Singapore SEMEO: Regional Center.

Richards, J. C. (1998). Beyond Training. Cambridge: Cambridge University Press.

Richards, J. C. (2001). The role of textbooks in a language program. Cambridge University Press.

Richards, J.C., Hull, J., \& Proctor, S. (2005). Interchange ( $3^{\text {rd }}$ Edition).Cambridge: Cambridge University Press.

Richards, J.C., Platt, J., \& Weber, H. (1985). Longman dctionary of applied linguistics. London: Longman.

Sarhady, T. (2009). A critical approach to English material development and language planning in Iran. Indian Journal of Applied Linguistics, 35(2), 143-153.

Sheldon, L. (1998). Evaluating ELT Textbooks and Materials. ELT Journal, 42(4), 237-246.

Skierso, A. (1991). Textbook selection and evaluation. In M. Celce-Murcia (Ed.), Teaching English as a second or foreign language (pp. 432-453). Boston, MA: Heinle \& Heinle.

Soozandehfar, S.M., \& Sahargard, R. (2012).A textbook evaluation of speech acts and language functions in Top-Notch series. Theory and Practice in Language Studies. 1(12), 1831-1838.

Tok, H. (2010). TEFL textbook evaluation: From teachers' perspectives. Educational Research and Review, 5 (9), 508517.

Tomlinson, B. (2001). Materials development. In R. Carter, \& D. Nunan (Ed.), The Cambridge guide to teaching. English to speakers of other languages (pp. 66-71). Cambridge: Cambridge University Press. http://dx.doi.org/10.1017/CBO9780511667206.010

Tomlinson, B. (2003), Materials evaluation, in B. Tomlinson (Ed.), Developing materials for language teaching. London: Continuum.

Tucker, C. A. (1975). Evaluating beginning textbooks. English Teaching Forum, 13, 355-361.

Ur, P. (1996). A course in language teaching: Practice \& theory. Cambridge: Cambridge University Press.

Williams, D. (1983). Developing criteria for textbook evaluation. ELT Journal, 37(3), 251-255.

Xu, I. H. (2004). Investigating criteria for assessing ESL textbooks. Unpublished doctoral dissertation, University of Alberta, Edmonton, Canada. Retrieved April 2012 from: http://proquest.umi.com.

Yakhontova, T. (2001). Textbooks, contexts, and learners. English for Specific Purposes, 20, 397-415. Retrieved April 2012 from: www.elsevier.com/locate/esp.

Yarmohammadi, L (2002). The evaluation of pre-university textbooks. The Newsletter of the Iranian Academy of Science, 18, 70-87.

Zare Asl, H. R. (2007). A comparative in-depth evaluation of two preuniversity English textbooks. Unpublished master's thesis, Shiraz University, Iran. 